\title{
Lung secretion sol-phase proteins: comparison of sputum with secretions obtained by direct sampling
}

\author{
J WIGGINS, SL HILL, RA STOCKLEY \\ From the General Hospital, Steelhouse Lane, Birmingham, and the Immunodiagnostic Research Laboratory, \\ University of Birmingham
}

ABSTRACT The protein content of tracheal secretions and of bronchial lavage and bronchoalveo $\overrightarrow{0}$ lar lavage fluid was compared with that of sputum in 33 patients who underwent fibreoptic bronchoscopy. The secretion-to-serum concentration ratios for albumin, $\alpha_{1}$-antitrypsin, $\alpha_{1}=$ antichymotrypsin, and immunoglobulin A (IgA) fell progressively as samples were obtained from further down the bronchial tree, probably reflecting greater sample dilution. The secretion-to $\frac{\mathbb{O}}{0}$ serum protein ratios when standardised for the corresponding albumin ratio were similar in al: secretions studied. In particular, the $\operatorname{IgA}$ ratios were about eight times those of albumin and $\alpha_{1}$-antichymotrypsin ratios were about twice those of albumin, suggesting similar degrees oft "local production" of these proteins in all secretions studied. Some patients showed considerablẹ differences in $\operatorname{IgA}$ ratios between sputum and bronchial lavage fluid. The significance of these differences is not clear.

Studies of the protein content of the lung secretions may provide information about the pathogenesis of lung diseases. Sputum is frequently studied because it is easy to collect and is therefore suitable for investigating large groups of patients. It is, however, a mixture of secretions from different areas of the bronchial tree and may not be representative of all parts of the respiratory tract. Furthermore, sputum is variably contaminated with saliva, although this effect may be largely dilutional. ${ }^{1}$

The problem of salivary contamination can be overcome by direct sampling of secretions during fibreoptic bronchoscopy, and this technique allows secretions to be selectively sampled from areas of the bronchial tree most relevant to the disease being studied. This means an invasive procedure, however, and the technique is less suitable for large population studies. Furthermore, the secretions obtained are also subject to variable dilution by anaesthetic solutions, used during the bronchoscopy, and by saline, which is used for lavaging the lung to obtain secretions from the lower respiratory tract.

The purpose of the present study was to compare

Address for reprint requests: Dr R A Stockley, General Hospital, Steelhouse Lane, Birmingham B4 6NH. the protein composition of sputum with that of se cretions obtained from different areas of the bron $\frac{3}{3}$ chial tree during fibreoptic bronchoscopy.

\section{Methods}

Thirty-three patients (eight female) were studied The average age was 62 years (range 29 to 77 yearsi and most (28) had chronic cough and sputum pro duction with irreversible airflow obstruction (meag forced expiratory ratio (FEV $/ \mathrm{FVC}$ ) $58.9 \%$, SD $12 \%)$. The patients underwent fibreoptic broncho scopy for a variety of reasons -15 patients had pul monary neoplasia, 14 unexplained haemoptysis, and four interstitial lung disease.

Fibreoptic bronchoscopy was performed afte premedication with intramuscular atropine $0.6 \mathrm{mgg}$ and intravenous diazepam $10 \mathrm{mg}$. The bronchow scope was passed transnasally after local anaesthesia with lignocaine and passed between the vocal cord after spraying them with two 2-ml aliquots of $4 \%$ lignocaine solution.

SECRETIONS STUDIED

Sputum This was collected as free from saliva possible over a three-hour period from 19 patien on the morning of bronchoscopy, before premedic 
tion. Samples were centrifuged at $54000 \mathrm{~g}$ for 90 minutes to obtain the sol phase, which was stored at $-70^{\circ} \mathrm{C}$ with a corresponding serum sample until analysis.

Tracheal secretions These were obtained from 23 patients and consisted of all secretions aspirated into a sterile trap from the vocal cords to the carina as the bronchoscope was advanced.

Bronchial lavage fluid This consisted of secretions aspirated from either the right or the left main bronchus after the instillation of 5-10 ml of sterile normal saline. The procedure was performed on 10 patients.

Bronchoalveolar lavage fluids The bronchoscope was gently wedged in a segmental or subsegmental bronchus of either the right middle lobe or the lingula in 31 of the patients. Aliquots of $20 \mathrm{ml}$ of sterile normal saline were instilled and then gently aspirated into a sterile trap. The procedure was repeated until $60-120 \mathrm{ml}$ had been instilled. The volume of fluid aspirated for analysis varied widely, from 10 to $40 \mathrm{ml}$.

In patients with obvious neoplasms the lavaged secretions were obtained from the clinically unaffected lung. The tracheal secretions and bronchial lavage and bronchoalveolar lavage fluids obtained were centrifuged at $54000 \mathrm{~g}$ for 90 minutes and stored with corresponding serum samples at $-70^{\circ} \mathrm{C}$ until subsequent analysis.

\section{PROTEINS STUDIED}

Before estimation of protein concentrations in bronchoalveolar lavage fluids the samples were concentrated, by a known factor (5-10-fold), with an Amicon pressure-filtration system with a UM2 membrane (molecular weight cut-off 2000 daltons). The protein concentrations obtained were then divided by this known concentration factor to obtain the protein concentration of the secretion in the unconcentrated lavage fluid.

The concentrations of albumin, $\alpha_{1}$-antitrypsin, $\alpha_{1}$-antichymotrypsin, and $\operatorname{IgA}$ were measured in all the secretions, monospecific antisera produced in the Birmingham University immunodiagnostic research laboratory being used. The results were expressed as percentages of a standard reference serum $\left(100 \%\right.$ standard $\equiv$ albumin $44.4 \mathrm{~g} / \mathrm{l} ; \alpha_{1}$ antitrypsin $2.04 \mathrm{~g} / \mathrm{l} ; \alpha_{1}$-antichymotrypsin $0.43 \mathrm{~g} / \mathrm{l}$; $\operatorname{IgA} 1.57 \mathrm{~g} / \mathrm{l})$. The secretion-to-serum concentration ratios were calculated to overcome variations between individual patients in the serum concentrations of the acute-phase proteins $\alpha_{1}$-antitrypsin and $\alpha_{1}$-antichymotrypsin, as described previously. ${ }^{2}$

The secretion-to-serum concentration ratios of $\alpha_{1}$-antitrypsin, $\alpha_{1}$-antichymotrypsin, and $\operatorname{IgA}$ were "standardised" for albumin by dividing each one by the corresponding albumin ratio to allow comparison of the relative protein concentrations of each secretion and to assess the presence and degree of local protein production. ${ }^{3}$

\section{Results}

The individual secretion-to-serum albumin concentration ratios for each sample are shown in figure 1 . The range was wide in all secretions studied (median values, with ranges, are given in table 1).

There was a progressive decrease in the values the more peripherally the secretions were obtained from the bronchial tree. This is emphasised in figure 2 , which shows the albumin results for three secretions obtained from the same nine patients. Similar results were found for secretion-to-serum $\alpha_{1}$-antitrypsin, $\alpha_{1}$-antichymotrypsin, and $\operatorname{IgA}$ concentration ratios (table 1).

"Standardisation" of the protein secretion-toserum ratios for albumin (that is, division by the

Table 1 Secretion-to-serum protein concentration ratios* (median values with ranges in parentheses)

\begin{tabular}{|c|c|c|c|c|}
\hline & $\begin{array}{l}\text { Sputum } \\
(n=19)\end{array}$ & $\begin{array}{l}\text { Tracheal } \\
\text { secretions } \\
(n=23)\end{array}$ & $\begin{array}{l}\text { Bronchial lavage } \\
\text { fluid } \\
(n=10)\end{array}$ & $\begin{array}{l}\text { Bronchoalveolar } \\
\text { lavage fluid } \\
(n=31)\end{array}$ \\
\hline $\begin{array}{l}\text { Albumin } \\
\alpha_{1} \text {-antitrypsin } \\
\alpha_{1} \text {-antitrypsin "corrected" for }\end{array}$ & $\begin{array}{l}0.71(0.23-18.42) \\
0.86(0.31-8.64)\end{array}$ & $\begin{array}{l}0.53(0.038-1.62) \\
0.29(0.028-1.08)\end{array}$ & $\begin{array}{l}0.044(0.019-0.84) \\
0.038(0.014-0.59)\end{array}$ & 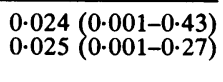 \\
\hline $\begin{array}{l}\text { albumin } \\
\alpha_{1} \text {-antichymotrypsin } \\
\alpha_{1} \text {-antichymotrypsin "corrected" }\end{array}$ & $\begin{array}{l}1 \cdot 04(0.47-2 \cdot 80) \\
2.73(0.79-4.49)\end{array}$ & $\begin{array}{l}0.75(0.095-1.75) \\
0.83(0.096-2.10)\end{array}$ & $\begin{array}{l}0.84(0.50-1.88) \\
0.20(0.033-1.32)\end{array}$ & $\begin{array}{l}0.79(0.13-1.42) \\
0.048(0.01-0.99)\end{array}$ \\
\hline $\begin{array}{l}\text { for albumin } \\
\text { IgA “"corrected" for albumin } \\
\text { IgA " }\end{array}$ & $\begin{array}{l}1.96(0 \cdot 15-15 \cdot 13) \\
9 \cdot 20(1 \cdot 80-49 \cdot 3) \\
7 \cdot 40(0 \cdot 60-44 \cdot 7)\end{array}$ & $\begin{array}{l}2 \cdot 34(0 \cdot 51-14.47) \\
5 \cdot 22(0 \cdot 59-6 \cdot 55) \\
8 \cdot 50(2 \cdot 02-40 \cdot 3)\end{array}$ & $\begin{array}{l}2 \cdot 32(1 \cdot 3-10 \cdot 53) \\
0 \cdot 56(0 \cdot 20-1 \cdot 20) \\
9 \cdot 30(1.43-21 \cdot 6)\end{array}$ & $\begin{array}{l}2 \cdot 00(0 \cdot 36-35 \cdot 5) \\
0 \cdot 39(0 \cdot 05-13 \cdot 7) \\
7 \cdot 75(1 \cdot 27-661 \cdot 7)\end{array}$ \\
\hline
\end{tabular}

*The $\alpha_{1}$-antitrypsin, $\alpha_{1}$-antichymotrypsin, and IgA values are "corrected" for (that is, divided by) the corresponding albumin result. All values are multiplied by 100 for convenience. 


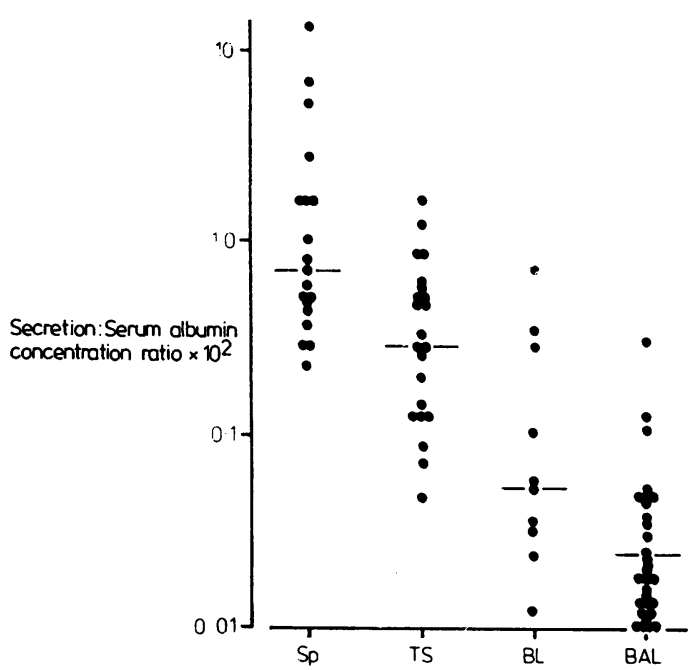

Fig 1 Secretion-to-serum albumin concentration ratios (values $\times 10^{2}$ for convenience). Each point represents the result from a single patient; horizontal lines are the median value for each secretion. Sp-sputum; TS-tracheal secretions; $B L-$ bronchial lavage fluid;

$B A L-$ bronchoalveolar lavage fuid.

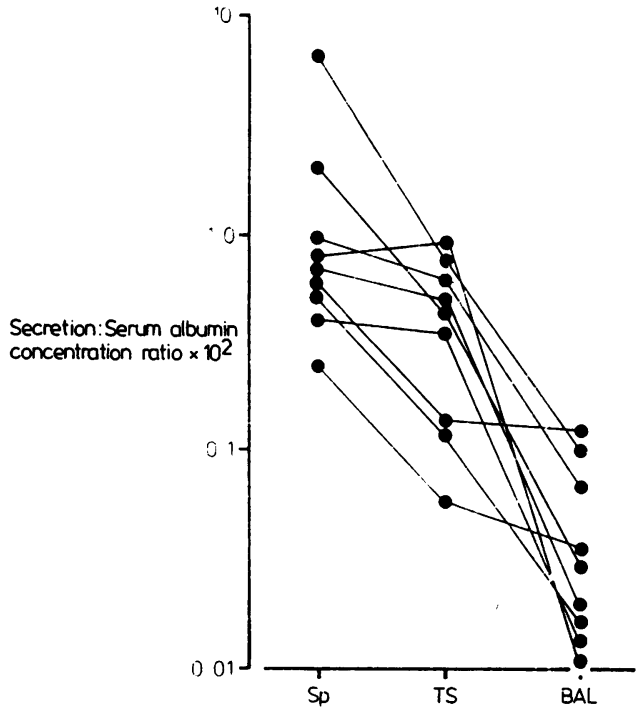

Fig 2 Secretion-to-serum albumin concentration ratios ( $\times$ $\left.10^{2}\right)$ for nine patients from whom matched sputum (Sp), tracheal sucking (TS), and bronchoalveolar lavage (BAL) samples were available. Each point represents the result from one patient; the lines join matched samples.

corresponding albumin value) gave similar results in all secretions studied. The results for $\alpha_{1}$-antitrypsin were close to unity, whereas $\operatorname{IgA}(\simeq 8)$ and $\alpha_{1}$ - antichymotrypsin $(\simeq 2)$ usually had a greater rati寓 than did albumin (table 1).

Median results (with ranges) for paired sample (that is, secretions obtained from the same patients are shown in table 2 . The median results were simi $\overline{\widetilde{ }}$ lar to those obtained from the whole group of patients. Secretion-to-serum albumin ratios im sputum were significantly higher than those in tracheal secretions $(2 p<0.01)$, which in turn were higher than those in bronchoalveolar lavage fluid, $(2 p<0.001)$. There were no significant differences between the "corrected" ratios of $\alpha_{1}$-antitrypsin $\times$ $\alpha_{1}$-antichymotrypsin, and $\operatorname{IgA}$ for any two secretionso studied.

Data from individual patients are shown in mores detail in figures 3 and 4 . Four secretions were obtained from nine patients and data for those indi $\frac{}{5}$ viduals are shown in table 3 . For those patient $\vec{s}$ there was also a progressive decrease in the secretion-to-serum protein ratios as sampling pro gressed down the bronchial tree (for clarity data fof albumin only are shown). The corrected secretionto-serum ratios for $\alpha_{1}$-antitrypsin, $\alpha_{1} 00$ antichymotrypsin, and $\operatorname{IgA}$ were similar in each ${ }^{\mathrm{s}}$ secretion.
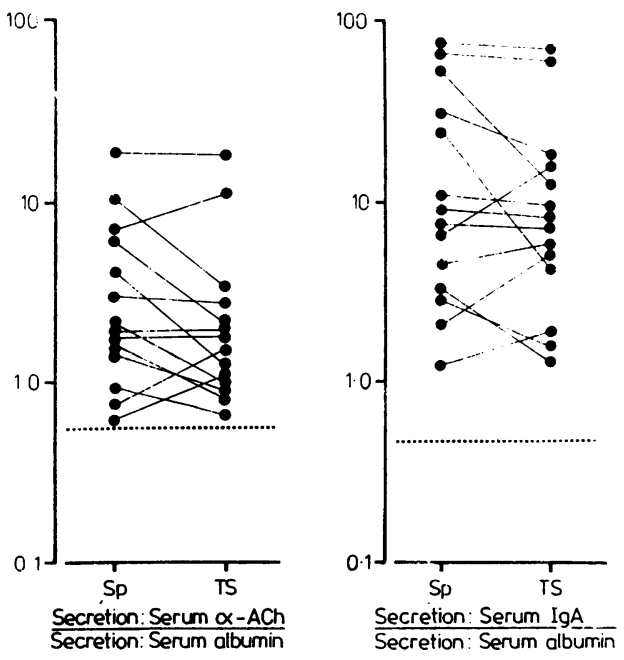

Fig 3 Secretion-to-serum $\alpha_{1}$-antichymotrypsin and IgA concentration ratios "corrected" for albumin: results in 14 patients from whom matched sputum (Sp) and tracheal sucking (TS) samples were available. Each point representse the result from one patient and the lines join paired samples. The broken lines represent the average value that would be expected for each protein if it behaved like albumin (that is entering lung secretions by simple transudation). Values above this line are consistent with "local" production of th\& protein. $\alpha_{1}-A C h-4 a_{1}$-antichymotrypsin. 
Table 2 Secretion-to-serum protein concentration ratios* for paired data (median values with ranges in parentheses)

\begin{tabular}{|c|c|c|c|c|}
\hline & \multicolumn{2}{|l|}{$(n=13)$} & \multicolumn{2}{|l|}{$(n=19)$} \\
\hline & Sputum & $\begin{array}{l}\text { Tracheal } \\
\text { secretions }\end{array}$ & Sputum & $\begin{array}{l}\text { Bronchoalveolar } \\
\text { lavage fuid }\end{array}$ \\
\hline Albumin $\times 100$ & $0.65(0.23-3 \cdot 14)$ & $0.49(0.04-1.62)$ & $0.71(0.23-18.42)$ & $0.03(0.01-0.12)$ \\
\hline $\begin{array}{l}\alpha_{1} \text {-antitrypsin } \\
\text { "corrected" }\end{array}$ & $1.05(0.84-2.30)$ & $0.87(0.22-1.75)$ & $1.04(0.47-2.80)$ & $0.75(0.13-1.29)$ \\
\hline $\begin{array}{l}\alpha_{1}-\text { antichymotrypsin } \\
\text { "corrected" } \\
\text { IgA "corrected" }\end{array}$ & $\begin{array}{l}2.14(0.50-15 \cdot 13) \\
7.40(1.26-44 \cdot 7)\end{array}$ & $\begin{array}{l}2.00(0.51-14.47) \\
8.69(2.02-40.31)\end{array}$ & $\begin{array}{l}1.96(0.15-15.13) \\
7.40(0.6-44.7)\end{array}$ & $\begin{array}{l}2.05(0.36-35 \cdot 5) \\
13.84(1.27-661 \cdot 7)\end{array}$ \\
\hline
\end{tabular}

"The $\alpha_{1}$-antitrypsin, $\alpha_{1}$-antichymotrypsin, and IgA results are shown "corrected" for (that is, divided by) the corresponding albumin results (which are multiplied by 100 for convenience).

Table 3 Secretion-to-serum protein concentration ratios* for nine patients from whom all four secretions were available (median values with ranges in parentheses)

\begin{tabular}{lllll}
\hline & Sputum & $\begin{array}{l}\text { Tracheal } \\
\text { secretions }\end{array}$ & $\begin{array}{l}\text { Bronchial lavage } \\
\text { fluid }\end{array}$ & $\begin{array}{l}\text { Bronchoalveolar } \\
\text { lavage fuid }\end{array}$ \\
\hline $\begin{array}{l}\text { Albumin } \times 100 \\
\alpha_{1} \text {-antitrypsin } \\
\text { "corrected" }\end{array}$ & $0.84(0 \cdot 37-3 \cdot 14)$ & $0.49(0 \cdot 12-1 \cdot 62)$ & $0.044(0 \cdot 026-0 \cdot 84)$ & $0 \cdot 029(0 \cdot 01-0 \cdot 064)$ \\
$\begin{array}{l}\alpha_{1} \text {-antichymotrypsin } \\
\text { "corrected" }\end{array}$ & $1.05(1 \cdot 04-1 \cdot 63)$ & $0.75(0 \cdot 22-0 \cdot 84)$ & $0.76(0 \cdot 5-1 \cdot 88)$ & $0 \cdot 79(0 \cdot 56-1 \cdot 29)$ \\
IgA "corrected" & $2 \cdot 14(0 \cdot 6-6 \cdot 23)$ & $1 \cdot 16(0 \cdot 51-2 \cdot 71)$ & $2 \cdot 32(1 \cdot 30-5 \cdot 00)$ & $1 \cdot 63(0 \cdot 77-3 \cdot 17)$ \\
\hline
\end{tabular}

*The $\alpha_{1}$-antitrypsin, $\alpha_{1}$-antichymotrypsin, and IgA results are shown "corrected" for the corresponding albumin result (which is multiplied by 100 for convenience).

Secretion: Serum IgA Secretion: Serum albumin

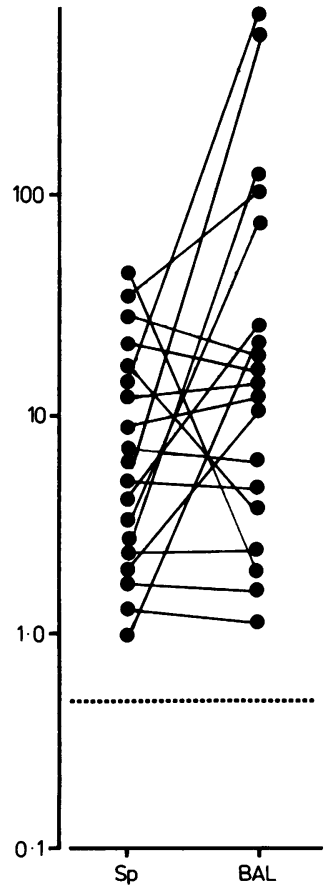

Fig 4 Secretion-to-serum IgA concentration ratios "corrected" for albumin: results from 19 patients from whom matched sputum (Sp) and bronchoalveolar lavage (BAL) samples were obtained. Each point represents the result from one patient and the lines join paired samples.

\section{Discussion}

The study of the protein content of lung secretions may provide clues to the pathogenesis of emphysema ${ }^{4}$ and the adult respiratory distress syndrome $^{5}$ and help in the diagnosis of lung cancer. ${ }^{6-8}$ Sputum is readily obtained from patients but is a mixture of secretions from all regions of the lung and nasopharynx. Furthermore, it is frequently contaminated with saliva to a variable extent, although the effect may be largely dilutional ${ }^{1}$; and it is not certain how representative sputum is of events in the more distal parts of the lung.

The sol-phase proteins albumin and $\alpha_{1}$-antitrypsin are both thought to enter the lung secretions by simple diffusion from the serum and their secretion-toserum ratios are similar in sputum ${ }^{1}$ and bronchoalveolar lavage fluid. ${ }^{3}$ IgA is produced locally within the lung and this is reflected in higher concentrations in sputum $^{9}$ and bronchoalveolar lavage fluid ${ }^{3810}$ than could be predicted on the basis of diffusion alone. But although local production of $\alpha_{1}$ antichymotrypsin is found in the sol phase of sputum of patients with chronic obstructive bronchitis ${ }^{12}$ Tegner failed to confirm it in bronchial lavage fluid from normal subjects. ${ }^{11}$ The present study was designed to assess the relative amounts of locally produced $\operatorname{IgA}$ and $\alpha_{1}$-antichymotrypsin in secretions from various parts of the bronchial tree to determine whether sputum is representative of other secretions in this respect. 
The secretion-to-serum concentration ratios for all proteins became progressively lower from sputum to bronchoalveolar lavage fluid. This effect is likely to be caused by the progressive dilution of the secretions. The tracheal secretions were diluted by variable amounts of the lignocaine used to anaesthetise the vocal cords. Bronchial lavage samples were further diluted by lignocaine and by the normal saline used during the lavage procedure. Finally, bronchoalveolar lavage fluids were greatly diluted by $60-120 \mathrm{ml}$ saline. To overcome this uncertain dilutional element, it is conventional to "standardise" the secretion by comparison with the albumin concentration. Albumin is thought to enter lung secretions by simple diffusion from serum. A protein which is either "locally produced" or preferentially concentrated within a lung secretion will be present in a greater concentration relative to albumin than in the corresponding serum. ${ }^{1}$ This simple technique for recognising local production can produce anomalous results when proteins of larger molecular size than albumin are studied, particularly in the presence of lung inflammation, ${ }^{9}$ which affects the permeability of the surface epithelium of the bronchial mucosa. It remains, however, a useful method for comparing different secretions in the same patient, since the relative protein concentrations should be similar unless the proportions of proteins produced locally or the degree of inflammation in various parts of the bronchial tree are also different.

The albumin and $\alpha_{1}$-antitrypsin secretion-toserum concentration ratios were similar in each secretion studied, confirming that the two proteins are behaving in the same way throughout the lung, entering all secretions by simple diffusion from serum. The IgA ratios were greater than albumin in all secretions studied, reflecting "local production" throughout the bronchial tree and providing confirmation that sputum is representative of this phenomenon. This confirms the findings of Masson et al, who showed similar IgA results in sputum and bronchial aspirates, ${ }^{12}$ and Mogi et al, who found a similarity between nasal, laryngeal, and tracheobronchial secretions, ${ }^{13}$ although the latter study included patients with laryngeal inflammation.

Evidence of local IgA production was also found in the bronchoalveolar lavage fluids studied here (with about eight times the albumin concentration), confirming the work of Reynolds and $\mathrm{Newball}^{3}$ and Warr et al. ${ }^{10}$ In the present study the median bronchoalveolar lavage fluid-to-serum $\operatorname{IgA}$ concentration ratio "standardised" for albumin was about eight times that of albumin, whereas the values of Warr et al, derived from normal subjects, were 12-16 times greater than albumin. ${ }^{10}$ Similarly, Reynolds and Newball found IgA ratios about
12-14 times greater than albumin in normal subjects, although less (8-10 times the albumin ratio) in patients with a variety of intrathoracic lesions (either minimal lung parenchymal lesions located in an upper lobe or asymmetrical mediastinal enlarge $-\frac{5}{-5}$ ment). This difference might be interpreted as reflecting reduced "local" IgA production in the patients of the present study and that of Reynoldsand Newball. Patients from both these studies are likely, however, to have had some degree of bron $\overrightarrow{\vec{\omega}}$ chial inflammation compared with normal subjects and this may give the impression of less "local" $\operatorname{IgA}{ }_{\times}^{\vec{*}}$ production where it is normal. ${ }^{9}$ The more complex techniques recently described by Stockley et al ${ }^{1 /} \mathrm{N}$ may overcome this problem.

Our study contirms comparable "local producN tion" of $\alpha_{1}$-antichymotrypsin in both sputum anc other lung secretions. This protein is an inhibitor of proteolytic enzymes and may protect tissues from ${ }_{\mathbb{D}}^{T}$ damage by leucocyte cationic proteases. ${ }^{15}$ The results are at variance with those of Tegner, ${ }^{11}$ who found no evidence for local production of $\alpha_{1}=$ antichymotrypsin in bronchial lavage fluid of normato subjects. For reasons discussed previously, ${ }^{2}$ how ever, the results of Tegner are difficult to interpret iro the absence of paired serum samples and they were from normal subjects, who may differ in this respec? from patients with bronchitis. Only five of our subڤ jects did not have chronic cough with sputum pro duction and their results were not clearly differen from the remaining 28 patients. The problem there fore remains unresolved and will require furthe studies.

In the present study centrifugation at $54000 \mathrm{~g}$ fo 90 minutes was used to obtain the sol phase, whiclo contains the freely diffusable proteins, from the sputum samples and also to remove debris from the other secretions studied. This speed was chosen t $\bar{\beta}$. enable comparison with our previous studies on lung secretions. $^{124914}$ There is no standard method o\$ preparation of lung secretions for immunologicab analysis, although other workers, using a variety of centrifugation techniques, ${ }^{381012}$ have obtaine $\Phi$ results in general agreement with those presented in the present paper. We consider that variations i centrifugation are unlikely to influence the results. $N$

The IgA-to-albumin and $\alpha_{1}$-antichymotrypsin to-albumin ratios in tracheal suckings were similaf to the values obtained in sputum from the same individuals. In this respect the secretions are biochemically comparable despite the presence of saliva and nasopharyngeal secretions in sputum Secretion-to-serum ratios ("corrected" for albumin $\bar{\phi}$ in sputum were comparable to the values obtaine in bronchoalveolar lavage fluid when the groupe data are considered. When matched samples frory 
the same individuals are examined, however, striking individual variation is revealed, particularly in the case of $\operatorname{IgA}$ (fig 4). The reason for these differences is not clear since the patients do not fall into distinct diagnostic groups. Further studies are required to determine the significance of this variation.

In conclusion, secretion-to-serum protein concentration ratios fall as sampling advances peripherally and this probably reflects greater sample dilution by anaesthetic and lavage fluid. The protein profile of sputum is similar to that of other secretions obtained during fibreoptic bronchoscopy, suggesting that a similar proportion of $\operatorname{IgA}$ and $\alpha_{1}{ }^{-}$ antichymotrypsin is locally produced in all secretions studied. The study of sputum proteins may well reflect changes in secretions from more distal areas of the lung. Major individual differences are seen in some patients, however, particularly with respect to $\operatorname{IgA}$.

We would like to thank Miss J Downs for her typing. The work was supported by the Medical Research Council, the West Midlands Regional Health Authority and the Endowment Fund. JW was a Sheldon clinical research fellow of the West Midlands Regional Health Authority.

\section{References}

${ }^{1}$ Stockley RA, Mistry M, Bradwell AR, Burnett D. A study of plasma proteins in the sol phase of sputum from patients with chronic bronchitis. Thorax 1979;34:777-82.

${ }^{2}$ Stockley RA, Burnett D. Alpha ${ }_{1}$ antichymotrypsin in infected and non infected sputum. Am Rev Respir Dis 1980;122:81-8.

${ }^{3}$ Reynolds HY, Newball HH. Analysis of proteins and respiratory cells obtained from human lungs by bronchial lavage. J Lab Clin Med 1974;84:559-73.

${ }^{4}$ Stockley RA, Burnett D. Alpha ${ }_{1}$ antitrypsin and leucocyte elastase in infected and noninfected sputum. Am Rev Respir Dis 1979;120:1081-6.

${ }^{5}$ Lee CT, Fein AM, Lippman M, Holtzman MD, Kimbel $P$, Weinbaum G. Elastolytic activity in pulmonary lavage fluids from patients with Adult Respiratory Distress Syndrome. N Engl J Med 1981;304:192-6.

${ }^{6}$ Merrill WW, Goodenburger D, Strober W, Matthay RA, Naegel GP, Reynolds HY. Free secretory component and other proteins in human lung lavage. Am Rev Respir Dis 1980;122:156-61.

${ }^{7}$ Merrill WW, Goodman M, Matthay RA, Naegel GP, Vandevoorde JP, Myl AD, Reynolds HY. Carcinoembryonic antigen in the lung lining fluids of smokers and non smokers. Am Rev Respir Dis 1981;123:29-31.

${ }^{8}$ Mandel MA, Dvorak KJ, Worman LW, De Cosse JJ. Immunoglobulin content in the bronchial washings of patients with benign and malignant pulmonary diseases. N Engl J Med 1976;295:694-8.

${ }^{9}$ Stockley RA, Burnett D. Local IgA production in patients with chronic bronchitis: effect of acute respiratory infection. Thorax 1980;35:202-6.

${ }^{10}$ Warr GA, Martin RR, Sharp PM, Rossen RD. Normal human bronchial immunoglobulins and protein. Effects of cigarette smoking. Am Rev Respir Dis 1977;116:25-30.

11 Tegner H. Quantitation of human granulocyte protease inhibitors in non purulent bronchial lavage fluids. Acta Otolaryngol (Stockh) 1978;85:282-9.

12 Masson PL, Heremans JF, Prignot J. Studies on the proteins of human bronchial secretions. Biochim Biophys Acta 1965;111:466-78.

${ }^{13}$ Mogi G, Watanabe N, Maeda S, Umehara T. Laryngeal secretions. An immunochemical and immunohistological study. Acta Otolaryngol 1979;87:129-41.

14 Stockley RA, Burnett D, Afford SC. The immunological measurement of "free" secretory piece and its relationship to local IgA production. Clin Exp Immunol 1981;45:124-30.

15 Ohlsson K, Åkesson U. $\alpha_{1}$ Antichymotrypsin interaction with cationic proteases from granulocytes. Clin Chim Acta 1976;73:285-9. 